\title{
Pengaruh Pupuk Lengkap Berpelepasan Hara Lambat (Slow Release Fertilizer) terhadap PertumbuhanVegetatif Tanaman Jeruk Siam (Citrus nobilis var. microcarpa Lour)
}

\section{Effects of Slow Release Fertilizer on Vegetative Growth of Tangerine (Citrus nobilis var. Microcarpa Lour)}

\author{
Dwi Kurnila Sari ${ }^{1 *}$, Sutopo $^{2}$, Slamet Supriyadi ${ }^{3}$ \\ ${ }^{1,3}$ Program Studi Agroteknologi, Fakultas Pertanian, Universitas Trunojoyo Madura \\ Jalan Raya Telang PO BOX 02 Kamal, Bangkalan, Madura \\ ${ }^{2}$ Balai Penelitian Tanaman Jeruk dan Buah Subtropika Indonesia \\ Jalan Raya Tlekung No. 1 PO BOX 22 Junrejo, Batu, Jawa Timur, Indonesia \\ *Email korespondensi: dwikurnilasari89@gmail.com
}

Diterima: 09 September 2019 / Disetujui: 13 Januari 2020

\begin{abstract}
Tangerine (Citrus nobilis var. microcarpa Lour) is one of the agricultural commodities having high economic and nutritional value. Application of slow release complex fertilizer containing all macro and micro nutrients) may reduce elemental loss and hence increase nutrient use efficiency. This study was to compare plant growth and NPK content in citrus leaves due to application of conventional fertilizer and PUKAP JESTRO SR. The study was conducted from October 2017 to March 2018 at the Punten Experimental Garden, ICSFRI, Malang. The research was arranged on Randomized Blok Design (RBD) with 12

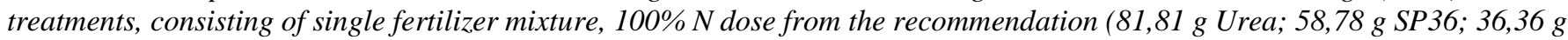
$\mathrm{KCl}$ ); NPK 15-15-15, NPK 16-16-16 each with 100\% $\mathrm{N}$ dose of the recommendation; NPK 16-16-16, 100\% N dose of the recommendation; PUKAP JESTRO SR 1, 2, and 3, each with 33\%, 66\%, and $100 \% \mathrm{~N}$ dose from the recommendation. Each treatment was replicated for three times. Data were analysed using ANOVA from SPSS Application. Whenever there was a significant effect of treatment, subsequently Contrast Orthogonal Method (MOK) $\alpha$ 5\% would be employed. Result of Leaf tissue analysis were interpreted by means of a Nutrient Adequacy Index. Result showed that citrus plant received by PUKAP JESTRO SR gave better vegetative growth than that of applied conventional fertilizers. PUKAP JESTRO SR dose N $33 \%$ could fulfill the nutrition needs for citrus plants from 6 to 9 months old, and the fertilizer type 1 (granule with coating) and 3 ( $\pm 5.0 \mathrm{~cm}$, noncoating) can be as an option. Leaf N content of citrus plant under SR JESTRO PUKAP was higher than that of plant received conventional fertilizers.
\end{abstract}

Keywords: conventional fertilizer, leaf NPK content, PUKAP JESTRO SR

\section{ABSTRAK}

Jeruk siam (Citrus nobilis var. microcarpa Lour) merupakan salah satu komoditas buah yang memiliki nilai ekonomi tinggi. Produksi jeruk siam dapat ditingkatkan, salah satu caranya dengan memenuhi kebutuhan nutrisi,baik makro maupun mikro.bedari pupukberpelepasan hara lambat. Penelitian ini dilakukan untuk membandingkan respon pertumbuhan tanaman serta kadar NPK daun jeruk siam akibat perlakuan pupuk konvensional dan PUKAP JESTRO SR 1, 2, dan 3. Penelitian dilakukan pada Oktober 2017 hingga Maret 2018 di Kebun Percobaan Punten, Balijestro, Malang. Perlakuan disusun dalam RAK dengan 12 taraf meliputi campuran pupuk tunggal, dosis $100 \% \mathrm{~N}$ dari rekomendasi (81,81 g Urea; 58,78 g SP36; $36,36 \mathrm{~g}$ KCl); NPK 15-15-15, NPK 16-16-16 masing-masing dengan dosis $100 \%$ N dari rekomendasi; PUKAP JESTRO SR 1, 2, 3 masing-masing dengan dosis 33\%, 66\% dan 100\% N dari rekomendasi. Setiap perlakuan diulang tiga kali. Analisis data menggunakan ANOVA aplikasi SPSS, dan apabila terdapat pengaruh perlakuan yang nyata, maka dilanjutkan dengan Metode Ortogonal Kontras (MOK) taraf $\alpha$ 5\%. Data hasil analisis kandungan hara dalam jaringan daun diinterpretasikan menggunakan perbandingan Indeks Kecukupan Hara Daun. Hasil analisis respon pertumbuhan tanaman, perlakuan PUKAP JESTRO SR memberikan pengaruh lebih baik daripada pupuk konvensional. Kadar N daun jeruk siam yang dipupuk PUKAP JESTRO SR lebih tinggi daripada tanaman yang dipupuk dengan pupuk konvensional. PUKAP JESTRO SR dosis N 33\% sudah mencukupi kebutuhan tanaman jeruk siam fase vegetatif umur 6 - 9 bula, dengan jenis 1 (granul dengan coating) dan 3 ( $\pm 5.0 \mathrm{~cm}$, non coating) dapat menjadi pilihan..

Kata Kunci:kandungan NPK daun, pupuk konvensional, PUKAP JESTRO SR 


\section{PENDAHULUAN}

Jeruk siam merupakan salah satu varietas jeruk yang mempunyai kontribusi besar dalam pemenuhan kebutuhan buah jeruk, terbukti dari 1.856.076 ton total produksi jeruk nasional, sebanyak 1.744 .330 ton $(93 \%)$ berasal dari produksi jeruk siam (Kementerian Pertanian, 2016). Petani umumnya menggunakan pupuk konvensional untuk menambahkan nutrisi pada tanaman. Permasalahannya pupuk konvensional,misalnya urea. memiliki efisiensi yang rendah. Aplikasi pupuk konvensional juga tidak praktis karena hanya mengandung satu atau beberapa unsur makro, sehingga memerlukan penambahan unsur pupuk lain. Pengelolaan hara secara efisien untuk mendapat produksi tinggi, namun tidak mencemari lingkungan dan biaya rendah menjadi penting dilakukan. Peningkatan efisiensi dapat dilakukan dengan aplikasi penggunaan pupuk slow release.

Trenkel (2010) menjelaskan pupuk slow release sebagai pupuk yang mampu melepaskan nutrisi yang dikandungnya secara perlahan setelah aplikasi sehingga pupuk menjadi tersedia dalam jangka waktu lebih lama dibanding pupuk konvensional pada umumnya.

Balai Penelitian Tanaman Jeruk dan Buah Subtropika telah merakit tiga jenis pupuk lengkap slow release (PUKAP JESTRO SR 1, 2, dan 3). Pupuk ini, selain bersifat slow release juga memiliki kandungan hara lengkap (makro dan mikro) sehingga aplikasinya lebih praktis, dan cocok diaplikasikan pada tanaman tahunan seperti jeruk karena mampu menyediakan nutrisi lebih lama. Kandungan N-nya yang tinggi, memungkinkan pupuk tersebut dapat direkomendasikan untuk tanaman jeruk pada fase vegetatif. Namun demikian, respon tanaman jeruk terhadap ketiga jenis pupuk tersebut masih belum diketahui, sehingga perlu dilakukan pengkajian lebih lanjut untuk mengetahui respon pertumbuhan tanaman dan kadar hara NPK daun jeruk siam yang dipupuk dengan PUKAP JESTRO SR dibandingkan pupuk konvensional yang direkomendasikan.

\section{METODE PENELITIAN}

\section{Tempat dan Waktu}

Penelitian dilakukan di Balai Penelitian Tanaman Jeruk dan Buah Subtropika Kebun Percobaan Punten, Batu di ketinggian tempat $\pm 950 \mathrm{~m} \mathrm{dpl}$. Penelitian dilakukan pada pada musim hujan, yaitu pada bulan Oktober 2017 sampai Maret 2018.

\section{Alat dan Bahan}

Alat yang digunakan yaitu sekop; timbangan digital ketelitian 0,0001 g; mistar ketelitian 1,0 mm; jangka sorong digital ketelitian 0,01 mm; beakerglass $2.000 \mathrm{~mL}$.

Bahan yang digunakan yaitu tanaman jeruk siam umur 6 bulan setelah okulasi; PUKAP JESTRO SR 1, 2, dan 3; pupuk NPK 16-16-16 (Mutiara), NPK 15-15-15 (Phonska), urea, $\mathrm{SP} 36, \mathrm{KCl}$; media tanam pasir kuarsa inert; polybag berdiameter $50 \mathrm{~cm}$ dan tinggi $60 \mathrm{~cm}$; air PDAM.

\section{Rancangan Penelitian}

Metode yang digunakan dalam penelitian ini adalah RAK (Rancangan Acak Kelompok) dengan 3 kali ulangan. Faktor jenis pupuk meliputi taraf:

$\mathrm{T}=$ Campuran pupuk tunggal (Urea, SP36, $\mathrm{KCl}), \quad 100 \% \mathrm{~N}$ dari dosis pupuk konvensional rekomendasi $(81,81 \mathrm{~g}$ Urea; 58,78 g SP36; 36,36 g KCl)

M1 = Pupuk NPK 15-15-15 (Phonska), $100 \% \mathrm{~N}$ dari dosis pupuk konvensional rekomendasi

M2 = Pupuk NPK 16-16-16 (Mutiara), $100 \% \mathrm{~N}$ dari dosis pupuk konvensional rekomendasi

$\mathrm{J} 1 \mathrm{~A}=$ PUKAP JESTRO SR $1,33 \% \mathrm{~N}$ dari dosis pupuk konvensional rekomendasi

$\mathrm{J} 1 \mathrm{~B}=$ PUKAP JESTRO SR $1,66 \% \mathrm{~N}$ dari dosis pupuk konvensional rekomendasi

$\mathrm{J} 1 \mathrm{C}=$ PUKAP JESTRO SR $1,100 \% \mathrm{~N}$ dari dosis pupuk konvensional Rekomendasi

$\mathrm{J} 2 \mathrm{~A}=$ PUKAP JESTRO SR 2, 33\% $\mathrm{N}$ dari dosis pupuk konvensional rekomendasi

$\mathrm{J} 2 \mathrm{~B}=$ PUKAP JESTRO SR 2, 66\% $\mathrm{N}$ dari dosis pupuk konvensional rekomendasi

$\mathrm{J} 2 \mathrm{C}=$ PUKAP JESTRO SR 2, 100\% $\mathrm{N}$ dari dosis pupuk konvensional rekomendasi

$\mathrm{J} 3 \mathrm{~A}=$ PUKAP JESTRO SR 3, 33\% $\mathrm{N}$ dari dosis pupuk konvensional rekomendasi

J3B = PUKAP JESTRO SR 3, 66\% $\mathrm{N}$ dari dosis pupuk konvensional rekomendasi

$\mathrm{J} 3 \mathrm{C}=$ PUKAP JESTRO SR 3, 100\% $\mathrm{N}$ dari dosis pupuk konvensional rekomendasi

Keterangan: PUKAP JESTRO SR 1 (Pupuk lengkap slow release ukuran granul coating 10\%); PUKAP JESTRO SR 2 (Pupuk lengkap slow release diameter $1,0 \mathrm{~cm}$ coating 10\%); PUKAP JESTRO SR 3 (Pupuk lengkap slow release diameter $5,0 \mathrm{~cm}$ noncoating).

Data parameter vegetatif (tinggi tanaman diukur dari titik 0 (titik permulaan tumbuhnya batang atas) sampai titik tumbuh; jumlah daun; jumlah cabang; panjang cabang; diameter batang diukur pada titik $3 \mathrm{~cm}$ dari titik 0) Analisis kadar NPK pada daun Jeruk Siam dilakukan pada akhir pengamatan yaitu tiga bulan setelah perlakuan. Pengambilan sampel daun dilakukan pada saat cuaca baik (antara pukul 08.00-12.00 WIB). Kriteria sampel daun yang diambil yaitu daun tua, sehat, tidak cacat dan diambil dari arah Utara, Selatan, Timur, dan Barat (Thamrin et al., 2015). Analisis kadar NPK daun di Laboratorium Tanah, Tanaman, Pupuk, Air BPTP Jawa Timur menggunakan metode pengabuan basah $\mathrm{H}_{2} \mathrm{SO}_{4}$ Kjeldahl untuk $\mathrm{N}$, pengabuan basah $\mathrm{H}_{2} \mathrm{NO}_{3}+\mathrm{HClO}_{4}$ spektrofotometri untuk $\mathrm{P}$, dan pengabuan basah $\mathrm{H}_{2} \mathrm{NO}_{3}+\mathrm{HClO}_{4}$ Atomic Absorption Spektroscopy (AAS) untuk K.

Data dianalisis menggunakan Analysis of Variance (ANOVA) aplikasi SPSS. Apabila terdapat pengaruh perlakuan yang nyata, maka dilanjutkan dengan Metode Ortogonal Kontras (MOK) taraf $\alpha 5 \%$. Data hasil analisis jaringan daun diinterpretasikan menggunakan Indeks Kecukupan Hara (Ref). 


\section{HASIL DAN PEMBAHASAN}

Perlakuan pupuk majemuk secara nyata meningkatkan diameter batang masing-masing sebesar 194 dan 156,4\% pada 1 dan 3 BSP, dan jumlah daun sebesar $572 \%$ pada 1 BSP dibandingkan perlakuan campuran pupuk tunggal. Masingmasing perlakuan tidak berpengaruh nyata terhadap jumlah daun pada 2 BSP (bulan setelah perlakuan) (Tabel 3.1).

Perbandingan rata-rata perlakuan pupuk NPK 16-1616 secara nyata meningkatkan jumlah daun sebesar 162,6\% pada 1 BSP dibandingkan pupuk NPK 15-15-15. Namun demikian, perbandingan rata-rata perlakuan pupuk NPK 1515-15 secara nyata meningkatkan jumlah cabang sebesar $98,2 \%$ pada 2 BSP dan $85 \%$ pada 3 BSP dibandingkan perlakuan pupuk NPK 16-16-16 (Tabel 3.2).
Perbandingan rata-rata perlakuan PUKAP JESTRO SR sangat nyata meningkatkan panjang cabang sebesar $1371 \%$ pada 1 BSP serta secara nyata meningkatkan tinggi tanaman sebesar $67,5 \%$ pada 1 BSP dan panjang cabang sebesar $91,5 \%$ pada 3 BSP dibandingkan rata-rata perlakuan pupuk majemuk. Masing-masing dari perlakuan tidak berpengaruh nyata terhadap parameter pada 2 BSP. (Tabel 3.3).

Perbandingan rata-rata perlakuan PUKAP JESTRO SR secara sangat nyata meningkatkan jumlah daun sebesar $516,1 \%$ pada 1 BSP serta secara nyata meningkatkan diameter batang sebesar $174,6 \%$ pada 1 BSP dan sebesar $150,8 \%$ pada 3 BSP dibandingkan perlakuan campuran pupuk Tunggal. Masing-masing perlakuan tidak berpengaruh nyata terhadap parameter pada 2 BSP. (Tabel 3.4).

Tabel 3.1 Rerata pertambahan diameter batang, jumlah daun, jumlah dan panjang cabang, dan tinggi tanaman jeruk akibat perlakuan jenis pupuk umur 1 dan 3 BSP

\begin{tabular}{|c|c|c|c|c|c|}
\hline \multirow{2}{*}{ Jenis Pupuk } & \multicolumn{5}{|c|}{ Variabel Pengamatan } \\
\hline & Diameter Batang (mm) & Jumlah Daun (helai) & Jumlah Cabang & Panjang Cabang $(\mathrm{cm})$ & Tinggi $(\mathrm{cm})$ \\
\hline \multicolumn{6}{|c|}{$1 \mathrm{BSP}$} \\
\hline $\mathrm{T}$ & 0,25 & 17,67 & 0,00 & 0,71 & 1,34 \\
\hline M1 & 0,52 & 65,50 & 1,66 & 0,00 & 1,25 \\
\hline M2 & 0,95 & 172,00 & 4,97 & 0,07 & 0,48 \\
\hline Sig. & $*$ & $*$ & ns & ns & ns \\
\hline \multicolumn{6}{|c|}{$3 \mathrm{BSP}$} \\
\hline $\mathrm{T}$ & 0,78 & 180,00 & 5,93 & 1,87 & 1,56 \\
\hline M1 & 1,83 & 414,92 & 10,25 & 0,28 & 2,32 \\
\hline M2 & 2,17 & 213,67 & 5,54 & 3,70 & 2,57 \\
\hline Sig. & $*$ & ns & ns & ns & ns \\
\hline
\end{tabular}

Keterangan: tanda ns, dan* menunjukkan tidak berbeda nyata, dan berbeda nyata menurut Uji MOK $\alpha$ 5\%, BSP (Bulan Setelah Perlakuan). T (Urea, SP36, KCl); M1 (Phonska/NPK 15-15-15); M2 (Mutiara/NPK 16-16-16).

Tabel 3.2 Rerata pertambahan diameter batang, jumlah daun, jumlah dan panjang cabang, dan tinggi tanaman jeruk akibat aplikasi pupuk NPK 16:16:16 dan NPK 15:15:15 umur 1,2, dan 3 BSP

\begin{tabular}{|c|c|c|c|c|c|}
\hline \multirow{2}{*}{ Jenis Pupuk } & \multicolumn{5}{|c|}{ Variabel Pengamatan } \\
\hline & Diameter Batang $(\mathrm{mm})$ & Jumlah Daun (helai) & Jumlah Cabang & Panjang Cabang $(\mathrm{cm})$ & Tinggi $(\mathrm{cm})$ \\
\hline \multicolumn{6}{|c|}{$1 \mathrm{BSP}$} \\
\hline M1 & 0,52 & 65,50 & 1,66 & 0,00 & 1,25 \\
\hline M2 & 0,95 & 172,00 & 4,97 & 0,07 & 0,48 \\
\hline Sig. & ns & $*$ & ns & ns & ns \\
\hline \multicolumn{6}{|c|}{$2 \mathrm{BSP}$} \\
\hline M1 & 1,25 & 423,48 & 10,05 & 0,28 & 2,31 \\
\hline M2 & 1,49 & 229,00 & 5,07 & 1,56 & 2,45 \\
\hline Sig. & ns & $\mathrm{ns}$ & $*$ & ns & ns \\
\hline \multicolumn{6}{|c|}{$3 \mathrm{BSP}$} \\
\hline M1 & 1,83 & 414,92 & 10,25 & 0,28 & 2,32 \\
\hline M2 & 2,17 & 213,67 & 5,54 & 3,70 & 2,57 \\
\hline Sig. & $\mathrm{ns}$ & $\mathrm{ns}$ & $*$ & ns & $\mathrm{ns}$ \\
\hline
\end{tabular}

Keterangan: tanda ns, dan *,menunjukkan tidak berbeda nyata, dan berbeda nyata menurut Uji MOK $\alpha$ 5\%, BSP (Bulan Setelah Perlakuan). M1 (NPK 15-15-15); M2 (NPK 16-16-16). 
Tabel 3.3 Hasil Uji Ortogonal Kontras Perlakuan Pupuk Majemuk dengan PUKAP JESTRO SR pada Berbagai Parameter Pengamatan

\begin{tabular}{|c|c|c|c|c|c|}
\hline \multirow{2}{*}{ Jenis Pupuk } & \multicolumn{5}{|c|}{ Variabel Pengamatan (Pertambahan) } \\
\hline & Diameter Batang (mm) & Jumlah Daun (helai) & Jumlah Cabang & Panjang Cabang $(\mathrm{cm})$ & Tinggi $(\mathrm{cm})$ \\
\hline \multicolumn{6}{|c|}{$1 \mathrm{BSP}$} \\
\hline M1 & 0,52 & 65,50 & 1,66 & 0,00 & 1,25 \\
\hline M2 & 0,95 & 172,00 & 4,97 & 0,07 & 0,48 \\
\hline $\mathrm{J} 1 \mathrm{~A}$ & 0,96 & 122,67 & 5,25 & 0,26 & 2,12 \\
\hline $\mathrm{J} 1 \mathrm{~B}$ & 0,96 & 114,00 & 4,52 & 0,12 & 0,45 \\
\hline $\mathrm{J} 1 \mathrm{C}$ & 0,62 & 79,00 & 4,17 & 0,17 & 0,21 \\
\hline $\mathrm{J} 2 \mathrm{~A}$ & 0,71 & 166,67 & 4,28 & 1,03 & 2,05 \\
\hline $\mathrm{J} 2 \mathrm{~B}$ & 0,49 & 235,33 & 4,45 & 0,09 & 1,60 \\
\hline $\mathrm{J} 2 \mathrm{C}$ & 0,36 & 27,33 & 0,82 & 0,29 & 1,38 \\
\hline $\mathrm{J} 3 \mathrm{~A}$ & 0,67 & 175,00 & 5,06 & 0,12 & 1,35 \\
\hline $\mathrm{J} 3 \mathrm{~B}$ & 0,66 & 39,33 & 2,16 & 1,47 & 2,88 \\
\hline $\mathrm{J} 3 \mathrm{C}$ & 0,65 & 20,33 & 1,62 & 0,86 & 1,07 \\
\hline Sig. & ns & ns & ns & $* *$ & $*$ \\
\hline \multicolumn{6}{|c|}{$3 \mathrm{BSP}$} \\
\hline M1 & 1,83 & 414,92 & 10,25 & 0,28 & 2,32 \\
\hline M2 & 2,17 & 213,67 & 5,54 & 3,70 & 2,57 \\
\hline $\mathrm{J} 1 \mathrm{~A}$ & 2,12 & 289,00 & 5,93 & 5,01 & 2,42 \\
\hline $\mathrm{J} 1 \mathrm{~B}$ & 2,04 & 266,67 & 6,10 & 2,47 & 1,52 \\
\hline $\mathrm{J} 1 \mathrm{C}$ & 2,12 & 187,33 & 7,19 & 1,87 & 1,53 \\
\hline $\mathrm{J} 2 \mathrm{~A}$ & 2,04 & 313,00 & 6,31 & 7,84 & 2,72 \\
\hline $\mathrm{J} 2 \mathrm{~B}$ & 1,96 & 368,00 & 6,49 & 4,63 & 2,08 \\
\hline $\mathrm{J} 2 \mathrm{C}$ & 1,67 & 195,67 & 4,92 & 3,53 & 1,65 \\
\hline $\mathrm{J} 3 \mathrm{~A}$ & 1,99 & 305,67 & 7,30 & 2,70 & 2,31 \\
\hline $\mathrm{J} 3 \mathrm{~B}$ & 1,96 & 345,33 & 7,04 & 4,06 & 3,17 \\
\hline $\mathrm{J} 3 \mathrm{C}$ & 1,77 & 360,67 & 9,02 & 2,16 & 1,40 \\
\hline Sig. & ns & ns & ns & $*$ & ns \\
\hline
\end{tabular}

Keterangan: tanda ns, *, dan ** menunjukkan tidak berbeda nyata, berbeda nyata, dan berbeda sangat nyata menurut Uji MOK $\alpha$ 5\%, BSP (Bulan Setelah Perlakuan). M1 (Phonska/NPK 15-15-15); M2 (Mutiara/NPK 16-16-16); J1, J2, J3 (PUKAP JESTRO SR granul coating 10\%, $\pm 1,0 \mathrm{~cm}$ coating $10 \%, \pm 5,0 \mathrm{~cm}$ noncoating); $\mathrm{A}, \mathrm{B}, \mathrm{C}$ (Dosis $33 \%, 66 \%, 100 \% \mathrm{~N}$ dari pupuk konvensional rekomendasi).

Perbandingan rata-rata perlakuan PUKAP JESTRO SR 1 secara nyata meningkatkan diameter batang sebesar $62,8 \%$ pada 1 BSP dibandingkan rata-rata perlakuan PUKAP JESTRO SR 2 (Tabel 3.5).

Perbandingan rata-rata perlakuan PUKAP JESTRO SR 1 dosis N 33\% secara nyata meningkatkan tinggi tanaman sebesar $545 \%$ pada 1 BSP dibandingkan dengan perlakuan PUKAP JESTRO SR 1 dosis N 66\% dan 100\% (Tabel 3.6).

Perbandingan rata-rata perlakuan PUKAP JESTRO SR 2 dosis N 33\% secara nyata meningkatkan panjang cabang sebesar $92,1 \%$ pada 3 BSP dibandingkan dengan perlakuan PUKAP JESTRO SR 2 dosis N 66\% dan 100\% (Tabel 3.7)

Perbandingan rata-rata perlakuan PUKAP JESTRO SR 3 dosis N 33\% secara nyata meningkatkan jumlah daun sebesar $486 \%$ pada 1 BSP dibandingkan dengan perlakuan PUKAP JESTRO SR 3 dosis N 66\% dan 100\% (Tabel 3.8).

Pengamatan terhadap pupuk PUKAP JESTRO SR setelah 4 bulan aplikasi, setelah dilakukan pengukuran massa pupuk menunjukkan PUKAP JESTRO SR 3 larut sebesar 14,4 \% dan PUKAP JESTRO SR 2 larut sebesar 26,67\% (Gambar 3.1).

Kadar N daun berdasarkan hasil perbandingan dengan Indeks Kecukupan Hara Daun (Srivasta, 2012) menunjukkan hasil optimum, kecuali akibat perlakuan jenis PUKAP
JESTRO SR 1 dosis N $66 \%$ termasuk rendah, perlakuan PUKAP JESTRO SR 2 dosis N 66\% dan $100 \%$ serta PUKAP JESTRO SR 3 dosis N 100\% termasuk tinggi (Gambar 3.2).

Kadar P daun akibat perlakuan PUKAP JESTRO SR 1 dosis N 33\% dan 100\%; PUKAP JESTRO SR 2 dosis N $33 \%$ dan 66\%; PUKAP JESTRO SR 3 dosis N 33\% termasuk rendah, sedangkan kadar P daun akibat perlakuan NPK 1515-15, NPK 16-16-16, campuran pupuk tunggal, PUKAP JESTRO SR 1 dosis N 66\%, PUKAP JESTRO SR 2 dosis N $100 \%$, dan PUKAP JESTRO SR 3 dosis N 100\% termasuk optimum (Gambar 3.3).

Kadar $\mathrm{K}$ daun akibat semua perlakuan jenis pupuk menunjukkan hasil yang rendah (Gambar 3.4). Campuran pupuk tunggal tidak lebih baik dari pupuk majemuk. Penelitian oleh Saputra et al. (2017) menunjukkan bahwa kandungan $\mathrm{N}$ pada tanaman karet belum menghasilkan yang menggunakan pupuk majemuk tablet lebih tinggi daripada campuran pupuk tunggal. Campuran pupuk tunggal tidak lebih baik dikarenakan mempunyai efisiensi yang lebih rendah dibandingkan pupuk majemuk. Rendahnya efisiensi pupuk tunggal (Urea dan $\mathrm{KCl}$ ) disebabkan kerentanannya terhadap leaching dan volatilisasi. Sholikah et al. (2013) mengungkapkan bahwa urea sangat cepat mengalami hidrolisis yaitu hanya membutuhkan waktu kurang dari lima 
hari setelah pengaplikasian untuk menjadi ammonium secara sempurna dan menguap sebagai amonia (Suwardi dan Darmawan, 2009). Oleh karena itu, pada dosis yang sama besar, frekuensi pemberian urea 3-4 kali lebih baik daripada yang diberikan 2 kali (Saragih et al., 2013).

Tabel 3.1 Hasil Uji Ortogonal Kontras Perlakuan Campuran Pupuk Tunggal dengan PUKAP JESTRO SR pada Berbagai Parameter Pengamatan

\begin{tabular}{|c|c|c|c|c|c|}
\hline \multirow{2}{*}{ Jenis Pupuk } & \multicolumn{5}{|c|}{ Variabel Pengamatan (Pertambahan) } \\
\hline & Diameter Batang (mm) & Jumlah Daun (helai) & Jumlah Cabang & Panjang Cabang $(\mathrm{cm})$ & Tinggi $(\mathrm{cm})$ \\
\hline \multicolumn{6}{|c|}{$1 \mathrm{BSP}$} \\
\hline $\mathrm{T}$ & 0,25 & 17,67 & 0,00 & 0,71 & 1,34 \\
\hline $\mathrm{J} 1 \mathrm{~A}$ & 0,96 & 122,67 & 5,25 & 0,26 & 2,12 \\
\hline $\mathrm{J} 1 \mathrm{~B}$ & 0,96 & 114,00 & 4,52 & 0,12 & 0,45 \\
\hline $\mathrm{J} 1 \mathrm{C}$ & 0,62 & 79,00 & 4,17 & 0,17 & 0,21 \\
\hline $\mathrm{J} 2 \mathrm{~A}$ & 0,71 & 166,67 & 4,28 & 1,03 & 2,05 \\
\hline $\mathrm{J} 2 \mathrm{~B}$ & 0,49 & 235,33 & 4,45 & 0,09 & 1,60 \\
\hline $\mathrm{J} 2 \mathrm{C}$ & 0,36 & 27,33 & 0,82 & 0,29 & 1,38 \\
\hline $\mathrm{J} 3 \mathrm{~A}$ & 0,67 & 175,00 & 5,06 & 0,12 & 1,35 \\
\hline $\mathrm{J} 3 \mathrm{~B}$ & 0,66 & 39,33 & 2,16 & 1,47 & 2,88 \\
\hline $\mathrm{J} 3 \mathrm{C}$ & 0,65 & 20,33 & 1,62 & 0,86 & 1,07 \\
\hline Sig. & $*$ & $* *$ & $*$ & ns & ns \\
\hline \multicolumn{6}{|c|}{$3 \mathrm{BSP}$} \\
\hline $\mathrm{T}$ & 0,78 & 180,00 & 5,93 & 1,87 & 1,56 \\
\hline $\mathrm{J} 1 \mathrm{~A}$ & 2,12 & 289,00 & 5,93 & 5,01 & 2,42 \\
\hline $\mathrm{J} 1 \mathrm{~B}$ & 2,04 & 266,67 & 6,10 & 2,47 & 1,52 \\
\hline $\mathrm{J} 1 \mathrm{C}$ & 2,12 & 187,33 & 7,19 & 1.87 & 1,53 \\
\hline $\mathrm{J} 2 \mathrm{~A}$ & 2,04 & 313,00 & 6,31 & 7,84 & 2,72 \\
\hline $\mathrm{J} 2 \mathrm{~B}$ & 1,96 & 368,00 & 6,49 & 4.63 & 2,08 \\
\hline $\mathrm{J} 2 \mathrm{C}$ & 1,67 & 195,67 & 4,92 & 3,53 & 1,65 \\
\hline $\mathrm{J} 3 \mathrm{~A}$ & 1,99 & 305,67 & 7,30 & 2,70 & 2,31 \\
\hline $\mathrm{J} 3 \mathrm{~B}$ & 1,96 & 345,33 & 7,04 & 4,06 & 3,17 \\
\hline $\mathrm{J} 3 \mathrm{C}$ & 1,77 & 360,67 & 9,02 & 2,16 & 1,40 \\
\hline Sig. & $*$ & ns & ns & ns & ns \\
\hline
\end{tabular}

Keterangan: tanda ns, *, dan ** menunjukkan tidak berbeda nyata, berbeda nyata, dan berbeda sangat nyata menurut Uji MOK $\alpha 5 \%$, BSP (Bulan Setelah Perlakuan). T (Urea, SP36, KCl); J1, J2, J3 (PUKAP JESTRO SR granul coating 10\%, $\pm 1,0 \mathrm{~cm}$ coating $10 \%, \pm 5,0 \mathrm{~cm}$ noncoating); A, B, C (Dosis 33\%, 66\%, 100\% N dari pupuk konvensional rekomendasi).

Tabel 3.5 Hasil Uji Ortogonal Kontras Perlakuan PUKAP JESTRO SR 1 dengan PUKAP JESTRO SR 2 pada Berbagai Parameter Pengamatan

\begin{tabular}{cccccc}
\hline \multirow{2}{*}{ Jenis Pupuk } & \multicolumn{5}{c}{ Variabel Pengamatan (Pertambahan) } \\
\cline { 2 - 6 } & \multicolumn{7}{c}{ Diameter Batang $(\mathrm{mm})$} & Jumlah Daun (helai) & Jumlah Cabang & Panjang Cabang (cm) & Tinggi (cm) \\
\hline J1A & 0,96 & 122,67 & 5,25 & 0,26 & 2,12 \\
J1B & 0,96 & 114,00 & 4,52 & 0,12 & 0,45 \\
J1C & 0,62 & 79,00 & 4,17 & 1,03 & 0,21 \\
J2A & 0,71 & 166,67 & 4,28 & 0,09 & 1,05 \\
J2B & 0,49 & 235,33 & 4,45 & 0,29 & ns \\
J2C & 0,36 & 27,33 & 0,82 & $\mathrm{~ns}$ & $\mathrm{~ns}$ \\
\hline Sig. & $*$ & $\mathrm{~ns}$ &
\end{tabular}

Keterangan: tanda ns, *, dan ** menunjukkan tidak berbeda nyata, berbeda nyata, dan berbeda sangat nyata menurut Uji MOK $\alpha$ 5\%, BSP (Bulan Setelah Perlakuan). J1, J2 (PUKAP JESTRO SR granul coating 10\%, $\pm 1,0 \mathrm{~cm}$ coating 10\%); A, B, C (Dosis 33\%, 66\%, 100\% N dari pupuk konvensional rekomendasi). 
Tabel 3.2 Hasil Uji Ortogonal Kontras Perlakuan PUKAP JESTRO SR 1 Dosis N 33\% dengan PUKAP JESTRO SR 1 Dosis N $66 \%$ dan $100 \%$ pada Berbagai Parameter Pengamatan

\begin{tabular}{cccccc}
\hline \multirow{2}{*}{ Jenis Pupuk } & \multicolumn{5}{c}{ Variabel Pengamatan (Pertambahan) } \\
\cline { 2 - 6 } & \multicolumn{7}{c}{ Diameter Batang $(\mathrm{mm})$} & Jumlah Daun (helai) & Jumlah Cabang & Panjang Cabang (cm) & Tinggi (cm) \\
\hline J1A & 0,96 & 1 BSP & 0,26 & 0,12 \\
J1B & 0,96 & 122,67 & 5,25 & 0,17 & 0,45 \\
J1C & 0,62 & 114,00 & 4,52 & 0,21 & ns \\
\hline Sig. & $\mathrm{ns}$ & 79,00 & 4,17 & $\mathrm{~ns}$ & $*$ \\
\hline
\end{tabular}

Keterangan: tanda ns, *, dan ** menunjukkan tidak berbeda nyata, berbeda nyata, dan berbeda sangat nyata menurut Uji MOK $\alpha$ 5\%, BSP (Bulan Setelah Perlakuan). J1 (PUKAP JESTRO SR granul coating 10\%); A, B, C (Dosis 33\%, 66\%, 100\% N dari pupuk konvensional rekomendasi).

Tabel 3.3 Hasil Uji Ortogonal Kontras Perlakuan PUKAP JESTRO SR 2 Dosis N 33\% dengan PUKAP JESTRO SR 2 Dosis N $66 \%$ dan $100 \%$ pada Berbagai Parameter Pengamatan

\begin{tabular}{cccccc}
\hline \multirow{2}{*}{ Jenis Pupuk } & \multicolumn{5}{c}{ Variabel Pengamatan (Pertambahan) } \\
\cline { 2 - 6 } & Diameter Batang $(\mathrm{mm})$ & Jumlah Daun (helai) & Jumlah Cabang & Panjang Cabang (cm) & Tinggi (cm) \\
\hline J2A & 2,04 & 313,00 & 6,31 & 7,84 & 2,72 \\
J2B & 1,96 & 368,00 & 6,49 & 4,63 & 2,08 \\
J2C & 1,67 & 195,67 & 4,92 & 3,53 & 1,65 \\
\hline Sig. & $\mathrm{ns}$ & $\mathrm{ns}$ & $\mathrm{ns}$ & $*$ \\
\hline
\end{tabular}

Keterangan: tanda ns, *, dan ** menunjukkan tidak berbeda nyata, berbeda nyata, dan berbeda sangat nyata menurut Uji MOK $\alpha$ 5\%, BSP (Bulan Setelah Perlakuan). J2 (PUKAP JESTRO SR diameter $\pm 1,0 \mathrm{~cm}$ coating $10 \%$ ); A, B, C (Dosis 33\%, 66\%, 100\% N dari pupuk konvensional rekomendasi).

Tabel 3.4 Hasil Uji Ortogonal Kontras Perlakuan PUKAP JESTRO SR 3 Dosis N 33\% dengan PUKAP JESTRO SR 3 Dosis N $66 \%$ dan $100 \%$ pada Berbagai Parameter Pengamatan

\begin{tabular}{cccccc}
\hline \multirow{2}{*}{ Jenis Pupuk } & \multicolumn{5}{c}{ Variabel Pengamatan (Pertambahan) } \\
\cline { 2 - 6 } & \multicolumn{7}{c}{ Diameter Batang $(\mathrm{mm})$} & Jumlah Daun (helai) & Jumlah Cabang & Panjang Cabang (cm) & Tinggi (cm) \\
\hline J3A & 0,67 & 175,00 & 5,06 & 0,12 & 1,35 \\
J3B & 0,66 & 39,33 & 2,16 & 1,47 & 0,86 \\
J3C & 0,65 & 20,33 & 1,62 & $\mathrm{~ns}$ & 1,07 \\
\hline Sig. & $\mathrm{ns}$ & $*$ & $\mathrm{~ns}$ & $\mathrm{~ns}$ \\
\hline
\end{tabular}

Keterangan: tanda ns, *, dan ** menunjukkan tidak berbeda nyata, berbeda nyata, dan berbeda sangat nyata menurut Uji MOK $\alpha$ 5\%, BSP (Bulan Setelah Perlakuan). J3 (PUKAP JESTRO SR 5,0 cm noncoating); A, B, C (Dosis 33\%, 66\%, 100\% N dari pupuk konvensional rekomendasi
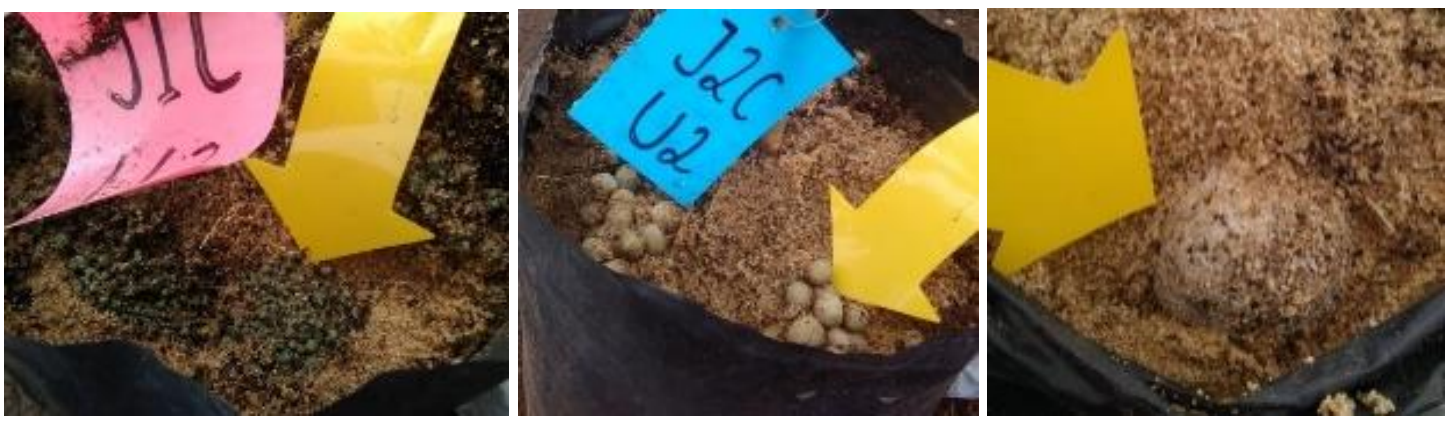

Gambar 31 Pupuk PUKAP JESTRO SR 1, 2, dan 3 setelah 4 Bulan aplikasi 


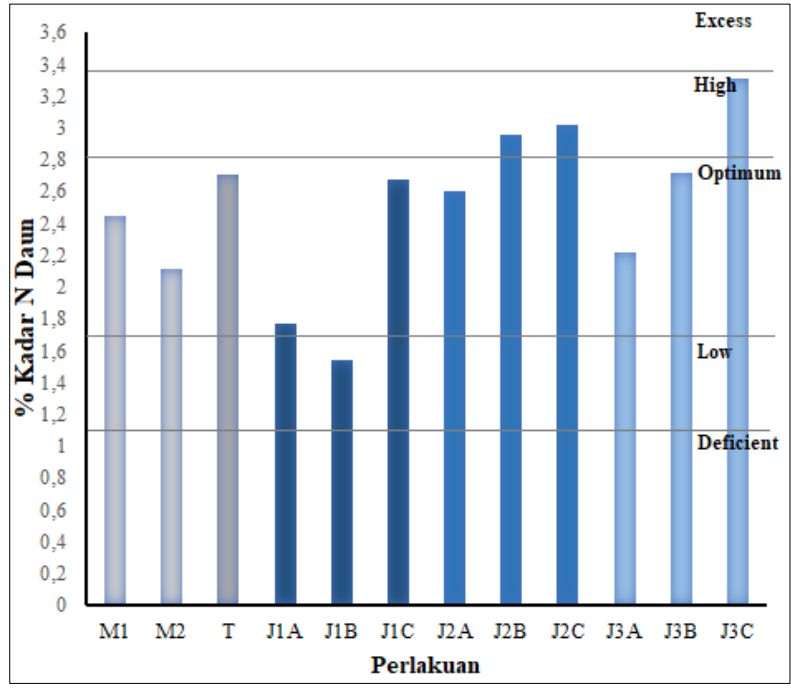

Gambar 32 Kecukupan Hara N dalam Daun Jeruk akibat Perlakuan Jenis Pupuk berdasarkan Indeks Nutrisi Daun (Srivasta, 2012)

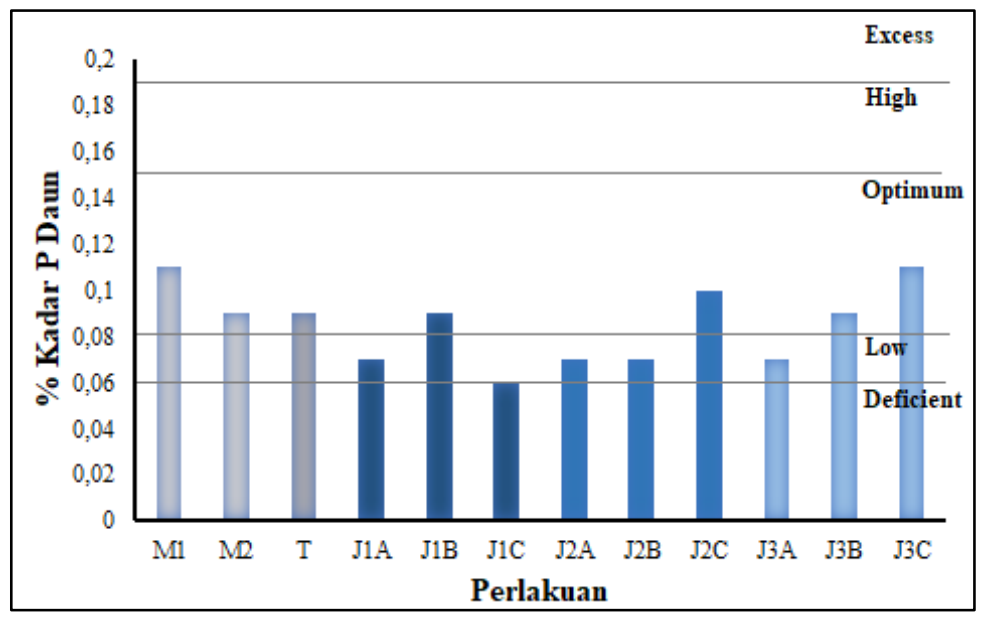

Gambar 33 Kecukupan Hara P dalam Daun Jeruk akibat Perlakuan Jenis Pupuk berdasarkan Indeks Nutrisi Daun (Srivasta, 2012)

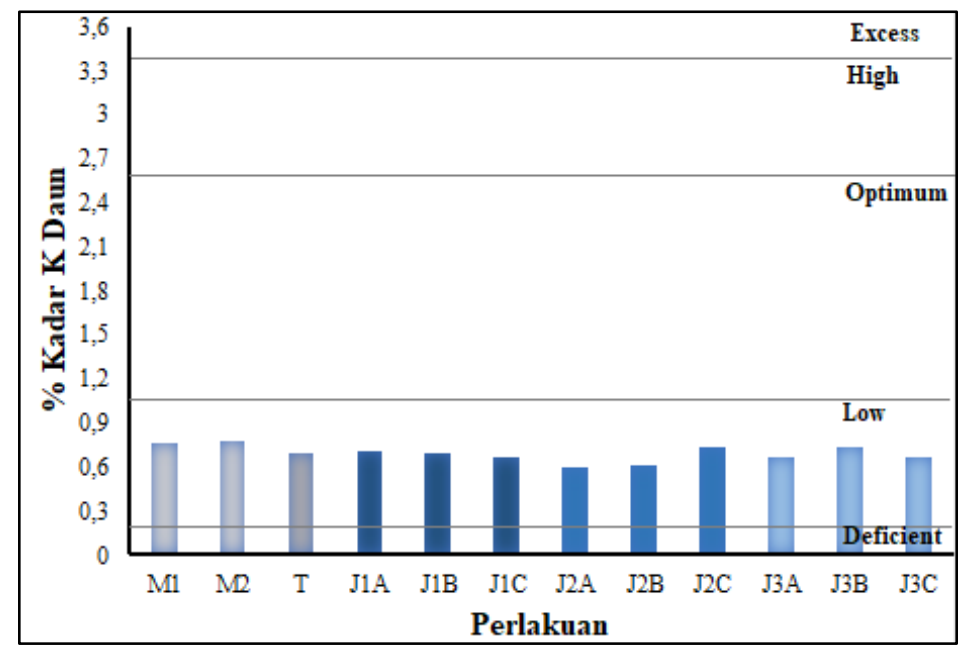

Gambar 34 Kecukupan Hara K dalam Daun Jeruk akibat Perlakuan Jenis Pupuk berdasarkan Indeks Nutrisi Daun (Srivasta, 2012) 
Pupuk majemuk memberikan pengaruh lebih baik daripada campuran pupuk tunggal dikarenakan selain mengandung unsur NPK juga unsur S dan Zn (pada pupuk NPK 15-15-15) serta tambahan unsur Mg dan Ca (pada pupuk NPK 16-16-16). Zekri dan Obreza (2012) menyatakan tanaman jeruk memerlukan pasokan nutrisi $\mathrm{Ca}$ dan $\mathrm{Mg}$ yang cukup disamping NPK. Pertumbuhan akan menjadi tidak optimal apabila satu atau lebih unsur ini tidak terpenuhi. Unsur $\mathrm{S}$ dan $\mathrm{N}$ saling berkaitan karena $\mathrm{S}$ merupakan penyusun dari banyak protein sebagaimana $\mathrm{N}$ serta memengaruhi metabolisme karbohidrat. Unsur $\mathrm{Mg}$ juga penting dalam proses fotosintesis karena berkaitan dengan penyusun materi klorofil (Zekri dan Obreza, 2016).

Aplikasi PUKAP JESTRO SR lebih baik daripada pupuk konvensional (campuran pupuk tunggal maupun majemuk). Hal ini dikarenakan sifatnya yang slow release. Pupuk slow release merupakan pupuk yang mampu menunda pelepasan hara setelah aplikasi dan kemudian melepaskannya menjadi bentuk tersedia bagi tanaman secara nyata dengan laju pelepasan lebih lambat daripada pupuk konvensional (FAO, 2000).

Pengaplikasian amonium nitrat 31 kali adalah sama baiknya dengan pengaplikasian pupuk $\mathrm{N}$ berpelepasan hara lambat 15 kali selama 7 tahun terhadap hasil buah dan kualitas jeruk "Hamlin". Diameter batang, kanopi dan peningkatan volume jeruk "Hamlin" lebih baik pada aplikasi pupuk N berpelepasan hara lambat dibanding amonium nitrat. (Rouse dan Obreza, 2006).

PUKAP JESTRO SR lebih baik dari pupuk konvensional dikarenakan selain bersifat slow release juga memiliki kandungan unsur lengkap. Zekri dan Obreza (2012) menyatakan bahwa pertumbuhan dan hasil panen tanaman jeruk sering dibatasi oleh unsur yang dibutuhkan dalam jumlah kecil (unsur mikro), sehingga untuk mencapai optimal diperlukan keseimbangan nutrisi makro dan mikro. Penelitian oleh Yaseen dan Ahmad (2010), menunjukkan bahwa aplikasi nutrisi mikro pada tanaman jeruk dapat meningkatkan produksi buah jeruk berkualitas (Kinnow) hingga 63\%. Tanaman jeruk yang terinfeksi HLB (Huanglongbin) atau dikenal sebagai CVPD dapat ditingkatkan massa akar dan pertumbuhannya ketika unsur mikro dari pupuk slow release, terutama Mn diterapkan tiga kali dari normal (Spyke et al., 2017).

Perlakuan PUKAP JESTRO SR 1 berbeda nyata dari PUKAP JESTRO SR 2 dikarenakan memiliki luas permukaan yang lebih besar. Octavia et al. (2012) menjelaskan ukuran partikel yang diperkecil dapat meningkatkan laju absorpsi dan mempengaruhi proses pelarutan.

Perlakuan PUKAP JESTRO SR 3 tidak berbeda nyata dengan PUKAP JESTRO SR 1 dan 2, meskipun luas permukaan PUKAP JESTRO SR 3 lebih kecil. Hal ini dikarenakan PUKAP JESTRO SR 3 tidak dilakukan penyalutan (coating) dengan zeolit, berbeda dengan PUKAP JESTRO SR 1 dan 2 yang dilakukan coating 10\%, meskipun ketiganya sama-sama mengandung zeolit didalamnya. Coating pada PUKAP JESTRO SR 1 dan 2 yang menyebabkan pelepasan hara hampir sama dengan PUKAP JESTRO SR 3 meskipun memiliki luas permukaan yang lebih besar. Zeolit dan gum yang digunakan sebagi bahan penyalut mampu menurunkan puncak pelepasan $\mathrm{NH}^{4+}$ dan $\mathrm{NO}^{3-}$ dan mengubah pola pelepasannya sehingga menjadi tersedia sampai akhir pengamatan (Sari, 2013). Zeolit merupakan mineral silikat yang memiliki kapasitas tukar kation sangat tinggi (80-180 meq/100 g), berongga sesuai ukuran ion ammonium sehingga mempunyai daya jerap yang tinggi terhadap ion ammonium (Pratomo et al., 2009). Marfuatun (2011) menjelaskan setiap 1,0 g zeolit alam mampu mengabsorpsi lebih dari 1,0 meq ion ammonium dan ion kalium pada pupuk, kemudian melepaskan ion-ion tersebut secara bertahap ke tanah (desorpsi) ketika konsentrasi kation tersebut dalam larutan tanah menurun.

Pemberian dosis N 33\% pada PUKAP JESTRO 1, 2, dan 3 mampu mendukung pertumbuhan tanaman jeruk pada fase vegetatif umur 9 bulan. Penelitian oleh Boman et al. (2007) menunjukkan bahwa tanaman jeruk "Midsweet" yang diberi perlakuan pupuk controlled release (sejenis pupuk berpelepasan hara lambat) aplikasi tahunan memiliki pertumbuhan setara dengan tanaman yang diberi perlakuan pupuk mudah larut kering pada interval 6 minggu maupun aplikasi fertigasi mingguan, walaupun tanaman jeruk dari perlakuan controlled release hanya menerima $44 \% \mathrm{~N}$ dibanding perlakuan lainnya.

Kebutuhan hara pada tanaman dapat diduga melalui analisis jaringan daun. Obreza dan morgan (2017) menjelaskan analisis jaringan daun secara luas telah digunakan sebagai alat untuk mendiagnosis kebutuhan hara pada tanaman tahunan sebelum terjadi gangguan hara.

Analisis daun menunjukkan bahwa kadar $\mathrm{N}$ daun jeruk akibat pemupukan dengan slow release (PUKAP JESTRO SR) menunjukkan hasil yang sama dengan pupuk cepat larut (konvensional) yaitu optimum, kecuali pada PUKAP JESTRO SR 2 dosis N 66\% dan 100\% serta PUKAP JESTRO SR 3 dosis N 100\% yang menghasilkan kadar N daun tinggi serta PUKAP JESTRO SR 1 dosis N 66\% termasuk rendah. Kadar N daun akibat perlakuan PUKAP JESTRO SR dosis N $33 \%$ menunjukkan lebih rendah daripada dosis N 66\% dan $100 \%$, akan tetapi memberikan pengaruh yang lebih baik terhadap pertumbuhan. Hal ini dikarenakan pada daya serap yang sama, unsur $\mathrm{N}$ yang terserap harus didistribusikan keseluruh organ tanaman. Roberts (2017) menjelaskan pelarutan mineral oleh pertumbuhan akan menjadi tinggi saat pertumbuhan tanaman sangat baik, sehingga kadar hara tampak lebih rendah meskipun tidak demikian pada kenyataannya. Penelitian oleh Roccuzzo et al. (2012), serapan hara $\mathrm{N}, \mathrm{P}, \mathrm{K}, \mathrm{Ca}, \mathrm{Mg}$ pada daun jeruk fase vegetatif menunjukkan bahwa kandungan pada daun tertinggi adalah $\mathrm{Ca}>\mathrm{N}>\mathrm{K}>\mathrm{Mg}>\mathrm{P}$. Unsur $\mathrm{Ca}$ dan $\mathrm{Mg}$ yang terserap sebagian besar ditemukan di daun, unsur $\mathrm{P}$ dan $\mathrm{K}$ yang terserap sebagian besar ditemukan pada buah, sedangkan unsur $\mathrm{N}$ ditemukan merata pada batang, daun, dan buah. Oleh karena itu, pada pertumbuhan yang baik akibat perlakuan PUKAP JESTRO SR dosis N 33\%, kadar N daun tidak lebih tinggi daripada dosis N 66\% dan 100\%. Sebaliknya pada dosis yang lebih tinggi, PUKAP JESTRO SR 66\% dan 100\% memiliki kadar $\mathrm{N}$ daun tinggi tetapi pengaruhnya terhadap pertumbuhan tidak lebih baik dari dosis N 33\%. Tanaman secara terus menerus akan meningkatkan absorpsi hara lebih 
dari yang dibutuhkan saat unsur yang tersedia tinggi sehingga terjadi penekanan pertumbuhan tanaman (Lakitan, 2008).

Kadar P daun jeruk akibat pemupukan konvensional dan PUKAP JESTRO SR pada dosis $66 \%$ dan $100 \%$ berada pada kondisi optimum, kecuali pada PUKAP JESTRO SR 1 dosis $100 \%$ termasuk rendah. Pemupukan PUKAP JESTRO SR dosis $33 \%$ menghasilkan kadar P daun yang rendah.

Kadar N daun akibat perlakuan PUKAP JESTRO SR 1 dosis N 66\% lebih rendah dari dosis 33\% begitupula kadar $\mathrm{P}$ daun akibat perlakuan PUKAP JESTRO SR 1 dosis $100 \%$ lebih rendah daripada dosis $33 \%$ dan $66 \%$. Hal ini diduga karena faktor perakaran. Roberts (2017) menyatakan akar memiliki peranan penting dalam proses penyerapan hara di tanah. Pemenuhan hara tanaman yang optimum memerlukan sistem perakaran yang berkembang baik dan aktif dalam proses penyerapan hara, apabila hal ini tidak terpenuhi maka akar tidak akan mampu memenuhi semua kebutuhan hara tanaman untuk pertumbuhannya.

Kalium daun jeruk akibat pemupukan konvensional maupun PUKAP JESTRO SR adalah sama rendah. Prasetyo dan Suriadikarta (2006); Nursyamsi et al. (2007) menyatakan unsur hara $\mathrm{K}$ dan $\mathrm{P}$ tersedia lebih lambat karena sebagian besar terikat dalam tanah. Senyawa P sebagian besar memiliki daya larut atau ketersediaan yang rendah bagi tanaman, sedangkan unsur $\mathrm{K}$ bahkan relatif tidak tersedia meskipun hasil analisis tanah menunjukkan $\mathrm{P}$ dan $\mathrm{K}$ potensial yang tinggi sampai sangat tinggi. Oleh karena itu, kadar $\mathrm{P}$ daun jeruk optimum saat dosis pemupukan yang diberikan lebih tinggi (>33\%). Kadar $\mathrm{K}$ daun akibat pemupukan konvensional perlu ditingkatkan dengan melakukan pemupukan kembali atau peningkatan dosis untuk mencapai optimum, sedangkan pada tanaman jeruk yang dipupuk PUKAP JESTRO SR tidak perlu penambahan pupuk karena masih ada sekitar $80 \%$ pupuk yang belum larut dalam media tanam.

Pemupukan PUKAP JESTRO SR dosis N 33\% sudah mencukupi tanaman jeruk siam untuk tumbuh secara optimal jika ditinjau dari kadar $\mathrm{N}$ daun. Sedangkan berdasar kadar $\mathrm{P}$ dan $\mathrm{K}$ daun meskipun masih tergolong rendah, pemupukan PUKAP JESTRO SR tetap dapat digunakan untuk tanaman jeruk fase vegetatif karena pupuk yang larut masih $20 \%$. Ayunita (2014) menjelaskan unsur $\mathrm{N}$ diperlukan dalam jumlah yang tinggi untuk fase vegetatif tanaman, sedangkan unsur $\mathrm{P}$ dan $\mathrm{K}$ diperlukan dalam jumlah tinggi pada saat fase generatif untuk pembentukan bunga dan buah.

\section{SIMPULAN DAN SARAN}

\section{Simpulan}

1 Respon pertumbuhan tanaman jeruk siam akibat perlakuan campuran pupuk tunggal tidak lebih baik dari pupuk majemuk.

2 Respon pertumbuhan tanaman jeruk siam akibat perlakuan PUKAP JESTRO SR lebih baik dari campuran pupuk tunggal.

3 Respon pertumbuhan tanaman jeruk siam akibat perlakuan PUKAP JESTRO SR lebih baik dari pupuk majemuk.
4 Kadar N daun jeruk akibat pemupukan JESTRO SR lebih tinggi daripada dengan pemupukan konvensional. PUKAP JESTRO SR dosis N 33\% sudah mencukupi kebutuhan tanaman jeruk siam fase vegetatif umur 6 hingga 9 bulan dengan jenis 1 (granul coating 10\%) dan 3 $( \pm 5.0 \mathrm{~cm}$ noncoating) dapat menjadi pilihan.

\section{Saran}

1. Sebaiknya dilakukan penelitian lebih lanjut hingga PUKAP JESTRO larut 100\%, sehingga pengaruh serta efektivitas penggunaannya dapat diketahui dengan lebih baik.

2. Untuk mengkaji efisiensi penggunaan PUKAP JESTRO di kebun jeruk, maka perlu dilakukan uji coba pada jenis tanah, musim, serta lokasi yang berbeda.

3. Sebaiknya pada penelitian pot di lapang, dilakukan penampungan air pelindian dan analisis hara pada larutan tersebut untuk memastikan ada atau tidaknya leaching (pelindian).

\section{DAFTAR PUSTAKA}

[FAO] Food and Agriculture Organization. (2000). Fertilizer and Their Use. Rome [IT]: FAO and IFA. p.34.

Ayunita, I., A. Mansyoer, \& Sampoerno. (2014). Uji Beberapa Dosis Pupuk Vermikompos pada Tanaman Kacang Hijau (Vigna radiata L.). Jom Faperta 1 (2): 1-11.

Boman, B.J., M. Asce, \& A.M. Battikhi. (2007). Growth, Evapotranspiration, and Nitrogen Leaching from Young Lysimeter-Grown Orange Trees. Journal of Irrigation and Drainage Engineering, 133 (4): 350358.

Kementerian Pertanian. (2016). Outlook Jeruk. Jakarta: Pusat Data dan Sistem Informasi Pertanian. 88 Hal.

Lakitan, B. (2008). Dasar-Dasar Fisiologi Tumbuhan. Jakarta: Grafindo Persada. 206 Hal.

Marfuatun. (2011). Manfaat Zeolit dalam Bidang Pertanian dan Peternakan. Yogyakarta: UNY Press. 7 Hal.

Nursyamsi, K. Idris, S. Sabiham, D.A. Rachim, \& A. Sofyan. (2007). Sifat-Sifat Tanah Dominan yang Berpengaruh terhadap K Tersedia pada Tanah-Tanah yang Didominasi Smektit. Jurnal Tanah dan Iklim, 26: 1328.

Obreza, T.A. and K.T. Morgan. (2017). Nutrition of Florida Citrus Trees Second Edition. Florida: IFAS. p. 96.

Octavia, M.D., A. Halim, \& R. Indriyani. (2012). Pengaruh Besar Ukuran Partikel terhadap Sifat - Sifat Tablet Metronidazol. Jurnal Farmasi Higea, 4 (2): 74-92. 
Prasetyo, B.H. \& D.A. Suriadikarta. (2006). Karakteristik, Potensi, dan Teknologi Pengelolaan Tanah Ultisol untuk Pengembangan Pertanian Lahan Kering di Indonesia. Jurnal Litbang Pertanian 25 (2): 39-47.

Pratomo, K.R., Suwardi, \& Darmawan. (2009). Pengaruh Pupuk Slow Release Urea-Zeolit-Asam Humat (UZA) terhadap Produktivitas Tanaman Padi Var. Ciherang. Jurnal Zeolit Indonesia 8 (2): 83-89.

Roberts, T.L. (2017). 4T Hara Tanaman: Pedoman Peningkatan Manajemen Hara Tanaman. [Online]. Tersedia: http://seap.ipni.net/article/SEAP-3296 diakses pada 13 Mei 2018.

Roccuzzo, G., D. Zanotelli, M. Allegra, A. Giuffrida, B. F. Torrisi, A. Leonardi, A. Quinones, F. Intrigliolo, and M. Tagliavini. (2012). Assessing Nutrient Uptake by Field-Grown Orange Trees. Europ. J. Agronomy 41: 73-80.

Rouse, R.E. and T.A. Obreza. (2006). Long-term Response of 'Hamlin' Orange Trees to Controlled-release Nitrogen Fertilizers. HortScience 41 (2): 423-426.

Saputra, J., R. Ardika, \& T. Wijaya. (2017). Respon Pertumbuhan Tanaman Karet (Hevea brasiliensis) Belum Menghasilkan terhadap Pemberian Pupuk Majemuk Tablet. Jurnal Penelitian Karet 35 (1): 4958.

Saragih, D., H. Hamim, \& N. Nurmauli. (2013). Pengaruh Dosis dan Waktu Aplikasi Pupuk Urea dalam Meningkatkan Pertumbuhan dan Hasil Jagung (Zea Mays L.) Pioneer 27. J. Agrotek Tropika 1 (1): 50-54.

Sari, E.P. (2013). Formulasi Pupuk Nitrogen Lambat Tersedia dari Bahan Urea, Zeolit, serta Asam Humat dan Pengaruhnya terhadap Pertumbuhan Jagung. Bogor : IPB. 59 Hal.

Sholikah, M.H., Suyono, \& P.R. Wikandari. (2013). Efektivitas Kandungan Unsur Hara N pada Pupuk
Kandang Hasil Fermentasi Kotoran Ayam terhadap Pertumbuhan Tanaman Terung (Solanum melongena L.). UNESA Journal of Chemistry 2 (1): 131-136.

Spyke, P., J. Sherrod, \& J. Grosser. (2017). ControlledRelease Fertilizer: Boosts Health of HLB trees. Citrus Industry Magazine (part 1). pp. 10-14.

Srivastava, A.K. (2012). Advances in Citrus Nutrition. New York: Springer. p.477.

Suwardi \& Darmawan. (2009). Peningkatan Efisiensi Pupuk Nitrogen Melalui Rekayasa Kelat Urea-Zeolit-Asam Humat. Prosiding Seminar Hasil-Hasil Penelitian IPB. Hal. 516-517.

Suwardi. (2002). Prospek pemanfaatan Mineral zeolite di Bidang Pertanian. Jurnal Zeolit Indonesia 1 (1): 5-12.

Thamrin, M., Ruchjaniningsih, F. Djufry, \& M.P. Yufdy. (2015). Rekomendasi Pemupukan Berdasarkan Status Kandungan Hara N, P, dan K Daun pada Tanaman Jeruk Pamelo (Citrus maxima (Burm.) Merr.). J. Hort. 25 (3): 201-207.

Trenkel, M.E. (2010). Slow and Controlled Release and Stabilized Fertilizers: An Option for Enhancing Nutrient Use Efficiency in Agriculture. France: International Fertilizer Industry Association (IFA). p.163.

Yaseen, M. and M. Ahmad. (2010). Nutrition Management in Citrus: Effect of Multinutrients Foliar Feeding on The Yield of Kinnow at Different Locations. Pak. J. Bot. 42 (3): 1863-1870.

Zekri, M. \& T. Obreza. (2012). Importance of Nutrients for Citrus Trees. Florida: IFAS. pp. 6-16.

Zekri, M. \& T. Obreza. (2016). Magnesium (Mg) for Citrus Trees. Florida: IFAS. pp. 1-4. 